\title{
A Retrospective Study of Traumatic Dental Injuries in a Brazilian Dental Urgency Service
}

\author{
Orlando Aguirre GUEDES ${ }^{1}$ \\ Ana Helena Gonçalves de ALENCAR ${ }^{1}$ \\ Lawrence Gonzaga LOPES ${ }^{1}$ \\ Jesus Djalma PÉCORA ${ }^{2}$ \\ Carlos ESTRELA ${ }^{1}$ \\ ${ }^{1}$ Dental School, Federal University of Goiás, Goiânia, GO, Brazil \\ ${ }^{2}$ Ribeirão Preto Dental School, University of São Paulo, Ribeirão Preto, SP, Brazil
}

\begin{abstract}
Epidemiologic aspects of traumatic dental injuries (TDI) were evaluated in the permanent dentition in a sample of 847 patients treated at the Dental Urgency Service of the Dental School of the Federal University of Goiás, Brazil, between May 2000 and May 2008. The statistical treatment analyzed data from frequency distribution and chi-square test. The level of significance was set at 5\% for all analyses. The results showed a higher incident among males $(610 ; 72.01 \%)$ with mean age of $6-10$ year-old. Uncomplicated crown fracture (without pulp exposure) $(502 ; 26.95 \%)$, avulsion $(341 ; 18.30 \%)$ and complicated crown fracture (with pulp exposure) (330; $17.71 \%$ ) were the most prevalent TDI. The prevalence of trauma throughout the years showed proportionality, being observed a larger number of cases between July and September $(249 ; 29.39 \%)$. The most affected teeth were the maxillary central incisors $(65.65 \%)$, followed by the maxillary left lateral incisors $(19.67 \%)$. In 311 participants $(18.25 \%)$, only one tooth was involved, while in most patients $(536 ; 81.75 \%)$, TDI occurred in more than one tooth. Significant proportion $(82.27 \%)$ of traumatized teeth presented completely formed root apex. The main etiologic factors involved in TDI were falls (51.71\%), traffic accidents $(22.90 \%)$ and violence (5.67\%). Based on the obtained data, it may be concluded that accurate policies of TDI prevention must be established, capable of stimulating the exposure of appropriate protocols for management of these lesions. The prevalence of TDI in Goiânia subpopulation is compared to the prevalence reported in epidemiological studies in others populations.
\end{abstract}

Key Words: traumatic dental injury, tooth injuries, avulsion, epidemiology, dental education.

\section{INTRODUCTION}

The improvement of traumatic dental injuries (TDI) in permanent teeth illustrate important aspects that must be carefully planned, requiring several follow-up appointments, mainly due to the possible appearance sequels in the developing permanent dentition (1). This fact can be observed due to public health policies, particularly due to the decline of the dental caries observed in several countries.

The number of epidemiological studies involving the diagnosis of TDI is smaller than that compared to the number of studies existing on dental caries and periodontal disease in both developing and industrialized countries (2). Population studies about TDI demonstrate a prevalence that ranges from $3.9 \%$ to $58.6 \%$ (3).
Some Brazilian regions that have epidemiological data about dental trauma, like the southern and southeastern regions, have shown a prevalence ranging from $10.7 \%$ to $58.6 \%$ (4-6). The demographic specificities and the differences of each region, in addition to cultural, social, economical and etiological factors, must be considered in the analysis of a population. The increase of violence, traffic accidents, and engagement of children in sports activities have contributed to transform TDI in an emergent public health problem $(2,7)$.

TDI must be considered an important issue due to its high prevalence, mainly in areas of high social privation. TDI have a strong impact on children's and adolescent's life quality because they cause physical and emotional distress and may have a high negative interference on the social relationships $(2,5)$. 
Planning public health policies with emphasis on the prevention of episodes that result in TDI should be based on the regional knowledge of the main risk factors involved. Thus, based on the review of TDI epidemiological data from the Brazilian population and, considering the differences in the demographic, cultural, social and economic characteristics of each population, this study investigated the epidemiological aspects of TDI in the permanent dentition of patients treated at a Brazilian Dental Urgency Service.

\section{MATERIAL AND METHODS}

This cross-sectional study was based on clinical and radiographic data of all patients with TDI who attended the Dental Urgency Service of the Dental School of the Federal University of Goiás, Brazil, between May 2000 and May 2008. Cases with incomplete documentation or TDI affecting primary dentition were excluded. The following information were collected from each patient's files: age at time of injury, gender, permanent tooth type, type of dental injury, cause of injury, month when the TDI occurred, and the root maturation level. The causes of TDI were classified in 5 categories: 1 ) traffic accidents; 2) sports activities; 3) falls; 4) violence; 5 ) others. The type of TDI was classified, according to the system described by Andreasen and Andreasen (8). This study was approved by the local Research Ethics Committee (Process \#055/2005).

Data analysis was undertaken using SPSS for Windows 15.0 statistical software (SPSS Inc., Chicago, IL, USA), including frequency distribution and crosstabulation. Chi-squared tests were used to compare qualitative data and determine statistical significance at level of $5 \%$.

\section{RESULTS}

A total of 847 patients aged 6-64 years met the inclusion criteria and were enrolled in the study. The data are summarized in Table 1. The highest frequency of TDI was in the 6-10-year-old participants (31.52\%) followed by the 11-15-year-old participants (14.76\%). The distribution of patients by gender showed that males were more often affected $(72.01 \%)$ than females (27.99\%) (male:female ratio of $2.5: 1)$. When the etiology of TDI was analyzed, $51.71 \%$ were caused by falls, $22.90 \%$ by traffic accidents, $5.67 \%$ by violence, $5.43 \%$ by sports activities and $14.29 \%$ other episodes. The time of occurrence of TDI was fairly well dispersed throughout the months of the years. The monthly distribution showed that most cases occurred between July-September (29.39\%). From a total of 1,703 traumatically injured teeth, the maxillary arch (88.25\%) was more frequently involved than the mandibular arch $(11.75 \%)$. The most affected teeth were the maxillary central incisors $(65.65 \%)$, followed by the maxillary left lateral incisors (19.67\%). A total of 311 (18.25\%) patients suffered trauma to one tooth, while 536 patients $(81.75 \%)$ suffered trauma to more than one tooth. The most common type of injury was uncomplicated crown fracture (without pulp exposure) (26.95\%) followed by avulsion (18.30\%) and complicated crown fracture (with pulp exposure) (17.71\%). It was found that $82.27 \%$ of the traumatized teeth had complete root formation with closed apex and $17.73 \%$ had the apices just about to be complete.

There were no statistically significant differences $(p>0.05)$ between the data collected from patients' records for the occurrence of TDI.

\section{DISCUSSION}

Epidemiological knowledge of TDI adds valuable information on public health and, when associated with clinical observations and trials, it provide essential evidence to all the science segments (9).

The retrospective epidemiological evaluation developed in the present study was based on the verification of the clinical records of patients with TDI treated at a Dental Urgency Service during an 8-year period. The population treated in this service lives in a sector of the city with a low social and economical level. The TDI classification adopted in the present study was based on the criteria proposed by Andreasen and Andreasen (8), which include the injuries to the teeth, supporting structures, gingiva, and oral mucosa. This is based on anatomic, therapeutic and prognostic considerations.

The most frequently identified TDI in the present study were uncomplicated crown fractures (26.95\%), followed by dental avulsions (18.30\%). These results are in agreement with those of previous studies $(10,11)$, in which a larger number of TDI associated to the mineralized dental tissues were found. It should be mentioned that the present study was developed in a public outpatient service of a dental school, which treats patients with low socioeconomic level. The types of TDI observed were directly related to the place where the study was 
Table 1. Distribution of the epidemiological data according to the etiology of the traumatic dental injuries.

\begin{tabular}{|c|c|c|c|c|c|}
\hline & Fall (\%) & Traffic accidents (\%) & Sports activities (\%) & Violence (\%) & Others $(\%)$ \\
\hline \multicolumn{6}{|l|}{ Age $(n=847)$} \\
\hline $6-10$ & $202(23.85 \%)$ & $20(2.36 \%)$ & $11(1.30 \%)$ & $0(0.00 \%)$ & $34(4.01 \%)$ \\
\hline $11-15$ & $142(16.76 \%)$ & $36(4.25 \%)$ & $21(2.48 \%)$ & $7(0.83 \%)$ & $32(3.78 \%)$ \\
\hline $16-20$ & $40(4.72 \%)$ & $42(5.96 \%)$ & $9(1.06 \%)$ & $17(2.01 \%)$ & $17(2.01 \%)$ \\
\hline $21-25$ & $21(2.48 \%)$ & $47(5.55 \%)$ & $2(0.24 \%)$ & $10(1.18 \%)$ & $13(1.53 \%)$ \\
\hline $26-30$ & $18(2.13 \%)$ & $19(2.24 \%)$ & $3(0.35 \%)$ & $9(1.06 \%)$ & $10(1.18 \%)$ \\
\hline $31-35$ & $6(0.71 \%)$ & $12(1.42 \%)$ & $0(0.00 \%)$ & $3(0.35 \%)$ & $6(0.71 \%)$ \\
\hline $36-40$ & $3(0.35 \%)$ & $8(0.94 \%)$ & $0(0.00 \%)$ & $2(0.24 \%)$ & $7(0.83 \%)$ \\
\hline $41-45$ & $4(0.47 \%)$ & $8(0.94 \%)$ & $0(0.00 \%)$ & $0(0.00 \%)$ & $0(0.00 \%)$ \\
\hline $46-50$ & $0(0.00 \%)$ & $1(0.12 \%)$ & $0(0.00 \%)$ & $0(0.00 \%)$ & $2(0.24 \%)$ \\
\hline $51-55$ & $1(0.12 \%)$ & $1(0.12 \%)$ & $0(0.00 \%)$ & $0(0.00 \%)$ & $0(0.00 \%)$ \\
\hline$>55$ & $1(0.12 \%)$ & $0(0.00 \%)$ & $0(0.00 \%)$ & $0(0.00 \%)$ & $0(0.00 \%)$ \\
\hline \multicolumn{6}{|l|}{ Gender $(n=847)$} \\
\hline Male & $307(36.25 \%)$ & $142(16.76 \%)$ & $39(4.60 \%)$ & $41(4.84 \%)$ & $81(9.56 \%)$ \\
\hline Female & $131(15.47 \%)$ & $52(6.14 \%)$ & $7(0.83 \%)$ & $7(0.83 \%)$ & $40(4.72 \%)$ \\
\hline \multicolumn{6}{|l|}{ Months (n=847) } \\
\hline January-March & $100(11.81 \%)$ & $45(5.31 \%)$ & $10(1.18 \%)$ & $10(1.18 \%)$ & $18(2.13 \%)$ \\
\hline April-June & $131(15.47 \%)$ & $50(5.90 \%)$ & $6(0.71 \%)$ & $10(1.18 \%)$ & $31(3.67 \%)$ \\
\hline July-September & $123(14.52 \%)$ & $60(7.08 \%)$ & $15(1.77 \%)$ & $15(1.77 \%)$ & $36(4.25 \%)$ \\
\hline October--December & $84(9.92 \%)$ & $39(4.60 \%)$ & $15(1.77 \%)$ & $13(1.53 \%)$ & $36(4.25 \%)$ \\
\hline \multicolumn{6}{|l|}{ Periodontal injury $(\mathrm{n}=1,863)$} \\
\hline Concussion & $9(0.48 \%)$ & $0(0.00 \%)$ & $0(0.00 \%)$ & $3(0.16 \%)$ & $1(0.05 \%)$ \\
\hline Subluxation & $149(8.00 \%)$ & $63(3.38 \%)$ & $11(0.59 \%)$ & $19(1.02 \%)$ & $29(1.56 \%)$ \\
\hline Extrusive luxation & $41(2.20 \%)$ & $20(1.07 \%)$ & $9(0.48 \%)$ & $1(0.05 \%)$ & $12(0.64 \%)$ \\
\hline Lateral luxation & $22(1.18 \%)$ & $30(1.61 \%)$ & $9(0.48 \%)$ & $11(0.59 \%)$ & $12(0.64 \%)$ \\
\hline Intrusive luxation & $25(1.34 \%)$ & $10(0.54 \%)$ & $1(0.05 \%)$ & $4(0.21 \%)$ & $6(0.32 \%)$ \\
\hline Avulsion & $159(8.53 \%)$ & $106(5.69 \%)$ & $9(0.48 \%)$ & $26(1.40 \%)$ & $41(2.20 \%)$ \\
\hline \multicolumn{6}{|l|}{ Dental hard tissue injury $(n=1,863)$} \\
\hline Crown infraction & $13(0.70 \%)$ & $4(0.21 \%)$ & $2(0.12 \%)$ & $2(0.12 \%)$ & $5(0.27 \%)$ \\
\hline Complicated crown fracture & $188(10.09 \%)$ & $72(3.86 \%)$ & $15(0.81 \%)$ & $14(0.75 \%)$ & $41(2.20 \%)$ \\
\hline Uncomplicated crown fracture & $272(14.60 \%)$ & $127(6.82 \%)$ & $17(0.91 \%)$ & $22(1.18 \%)$ & $64(3.44 \%)$ \\
\hline Complicated crown-root fracture & $8(0.43 \%)$ & $6(0.32 \%)$ & $3(0.16 \%)$ & $2(0.12 \%)$ & $6(0.32 \%)$ \\
\hline Uncomplicated crown-root fracture & $3(0.16 \%)$ & $0(0.00 \%)$ & $0(0.00 \%)$ & $0(0.00 \%)$ & $0(0.00 \%)$ \\
\hline Root fracture & $13(0.70 \%)$ & $32(1.72 \%)$ & $5(0.27 \%)$ & $4(0.21 \%)$ & $15(0.81 \%)$ \\
\hline \multicolumn{6}{|l|}{ Supporting tissue injury $(\mathrm{n}=1,863)$} \\
\hline Alveolar fracture & $12(0.64 \%)$ & $40(2.15 \%)$ & $0(0.00 \%)$ & $9(0.48 \%)$ & $2(0.12 \%)$ \\
\hline Mandibular fracture & $3(0.16 \%)$ & $3(0.16 \%)$ & $0(0.00 \%)$ & $0(0.00 \%)$ & $0(0.00 \%)$ \\
\hline Maxillary fracture & $0(0.00 \%)$ & $1(0.05 \%)$ & $0(0.00 \%)$ & $0(0.00 \%)$ & $0(0.00 \%)$ \\
\hline \multicolumn{6}{|l|}{ Root maturation level $(\mathrm{n}=1,703)$} \\
\hline Complete root formation & $622(36.52 \%)$ & $442(25.95 \%)$ & $64(3.77 \%)$ & $108(6.34 \%)$ & $165(9.69 \%)$ \\
\hline Incomplete root formation & $211(12.39 \%)$ & $36(2.11 \%)$ & $10(0.59 \%)$ & $0(0.00 \%)$ & $45(2.64 \%)$ \\
\hline \multicolumn{6}{|l|}{ Single/Multiple $(\mathrm{n}=1,703)$} \\
\hline Single & $160(9.38 \%)$ & $48(2.82 \%)$ & $24(1.41 \%)$ & $14(0.82 \%)$ & $65(3.82 \%)$ \\
\hline Multiple & $674(39.53 \%)$ & $431(25.28 \%)$ & $50(2.93 \%)$ & $94(5.51 \%)$ & $143(8.50 \%)$ \\
\hline
\end{tabular}


developed $(10,12)$. Therefore, more complex TDI cases are usually observed in people that seek treatment or are referred to hospitals. Patients that suffer crown fracture are usually seen at dental clinics, while for other types of trauma without symptoms or visible complications, frequently receive no treatment (13).

Male individuals suffered significantly more TDI in the permanent dentition than females, a 2.5:1 ratio. This fact is referred to in most epidemiological studies, with male-to-female ratios ranging from 1.3-2.78:1 (7). Men are the main victims of TDI probably because they are more frequently engaged in stronger physical activities, like physical contact sports, usually without wearing adequate protection, aggressive plays like fights or others, and use of different kinds of equipment and devices with higher potential of causing dental trauma. Other studies $(2,14)$ have demonstrated almost the same incidence of TDI in males and females.

TDI in the permanent dentition have been observed with a elevate frequency among 9 and 10 -year-old children (12). In this study, it was verified an elevated quantity of dental injuries among the 6 to 10 -year-old participants (31.5\%), which is in concordance with other investigations $(10,15)$. However, it is necessary to be careful at comparing the prevalence among the studies that use different methodologies.

The majority of TDI involved the maxillary central incisor $(65.65 \%)$, as reported elsewhere $(5,10,15)$. The vulnerable position of this tooth, which can often be found protracted and with inadequate labial coverage, may explain this result (16). The maxillary lateral incisor was the second most commonly involved tooth (19.67\%), as also verified by Rocha and Cardoso (17).

From the TDI cases evaluated in the present study, $81.75 \%$ involved more than one tooth. Some individuals presented the involvement of $3,4,5$ or even 11 teeth. These frequencies were almost the same to those found in previous investigations $(1,10,17)$, which verified that the majority of injuries involved multiple teeth. However, some epidemiological surveys (18) have demonstrated that the most TDI occur in a one tooth. This fact can be explained due to the differences in data collection among the different studies. The present study evaluated TDI to all permanent teeth, while other studies have investigated only injuries to anterior teeth for example. On the other hand, the number of affected teeth seems to vary according to the etiology of the trauma. More severe TDI, like those resulting from traffic accidents, may increase the number of involved teeth (13).
The causal factors identified in this study are in agreement with those conducted with other Brazilian populations $(5,16)$. In these surveys, the main causes of the injuries were falls $(26.0 \%)$, traffic accidents $(20.5 \%)$, sports activities $(19.2 \%)$, violence $(16.4 \%)$ and collisions with people or inanimate objects (1.4\%). Nicolau et al. (6) observed in a sample of 763 students aged 13 years from Cianorte, Paraná, Brazil, that TDI occurred most times as a consequence of collisions (15\%), while traffic accidents (10.5\%), sports activities (2.3\%) and violence $(1.5 \%)$ were less prevalent.

The etiological factors varied according to the age group studied, as the majority of TDI cases resulted from falls in children aged 6-10 and 11-15 years. With the increase of age, traffic accidents became the main etiologic agent, as reported elsewhere (19).

Although there are reports indicating the school vacation and summer as the periods of higher incidence of TDI (20), the results of the present survey did not show any relationship between these periods, finding a high incidence between July and September (29.39\%).

The importance of the present study is due to the lack of epidemiologic data on TDI in the permanent dentition of the population of Goiânia, GO, Brazil. The findings can help the development of preventive policies and the adoption more defined clinical decisions with therapeutic protocols. Future prospective studies based on the follow up of these patients are needed to evaluate the efficacy of the therapeutic protocols and their implications over time. At this moment, the best general prognostic of TDI points to preventive measures as a viable, functional and operational alternative, regardless of gender, age or social level.

Based on the obtained data, it may be concluded that accurate policies of TDI prevention must be established, capable of stimulating the exposure of appropriate protocols for management of these lesions. The prevalence of TDI in Goiânia subpopulation is compared to the prevalence reported in epidemiological studies in others populations.

\section{RESUMO}

Nexte estudo, avaliou-se os aspectos epidemiológicos das injúrias traumáticas na dentição permanente em uma amostra de 847 pacientes atendidos pelo Serviço de Urgência da Faculdade de Odontologia da Universidade Federal de Goiás, entre os anos de 2000 e 2008. O tratamento estatístico analisou os dados frente à distribuição de freqüência e qui-quadrado. O nível de significância foi de $\mathrm{p}<0,05$. Os resultados mostraram uma maior 
ocorrência entre os indivíduos do gênero masculino (72,01\%), na faixa etária 6-10 anos. A fratura coronária sem exposição do tecido pulpar $(502 ; 26,95 \%)$, avulsão $(341 ; 18,30 \%)$ e fratura coronária com exposição pulpar $(330 ; 17,71 \%)$ constituíram nas injúrias traumáticas mais prevalentes. A prevalência das injúrias traumáticas ao longo dos meses do ano mostrou-se proporcional, sendo observado um maior número de casos entre os meses de julho a setembro $(249 ; 29,39 \%)$. afetado foi o incisivo central superior $(65,65 \%)$, seguido pelo incisivo lateral superior esquerdo (19,67\%). Em 311 participantes (18,25\%) apenas um dente estava envolvido, enquanto que a maioria dos pacientes (536; 81,75\%), injúrias dentárias ocorreram em mais de um dente. Significativa proporção $(82,27 \%)$ dos dentes traumatizados apresentava os ápices radiculares completamente formados. Os principais fatores etiológicos envolvidos nos traumatismos dentários foram as quedas $(51,71 \%)$, acidentes automobilísticos $(22,90 \%)$, e violência $(5,67 \%)$. Adequadas políticas de prevenção de traumatismos dentários devem ser institucionalizadas, capaz de divulgar protocolos apropriados para o manejo destas lesões. A prevalência de traumatismos dentários em uma subpopulação de Goiânia é comparável a prevalência reportada em estudos epidemiológicos de outras populações.

\section{ACKNOWLEDGEMENTS}

This study was supported in part by grants from the Nacional Council for Scientific and Technological Development (CNPq grants $302875 / 2008-5$ to C.E.).

\section{REFERENCES}

1. Wright G, Bell A, McGlashan G, Vicent C, Welbury RR. Dentoalveolar trauma in Glasgow: an audit of mechanism and injury. Dent Traumatol 2007;23:226-231.

2. Marcenes W, Al Beiruti N, Tayfour D, Issa S. Epidemiology of traumatic injuries to the permanent incisors of 9-12-yearold schoolchildren in Damascus, Syria. Dental Traumatol 1999;15:117-123.

3. Glendor U. Epidemiology of traumatic dental injuries - a 12 year review of the literature. Dent Traumatol 2008;24:603-611.

4. Marcenes W, Zabot NE, Trabert J. Socio-economic correlates of traumatic injuries to the permanent incisors in schoolchildren aged 12 years in Blumenau, Brazil. Dent Traumatol 2001;17:222-226.

5. Côrtes MIS, Marcenes W, Sheimam A. Prevalence and correlates of traumatic injuries to the permanent teeth of school-children aged 9-14 years in Belo Horizonte, Brazil. Dental Traumatol 2001;17:22-26

6. Nicolau B, Marcenes W, Sheiham A. Prevalence, causes and correlates of traumatic dental injuries among 13-year-olds in Brazil. Dent Traumatol 2001;17:213-217.

7. Bastone EB, Freer TJ, McNamara JR. Epidemiology of dental trauma: a review of literature. Aust Dent J 2000;45:2-9.

8. Andreasen JO, Andreasen FM, Andersson L. Textbook and color atlas of traumatic injuries to the teeth. 4th ed. Oxford: Blackwell; 2007, 770p.

9. Love RM, Ponnambalam Y. Dental and maxillofacial skeletal injuries seen at the University of Otago school of dentistry, New Zealand 2000-2004. Dental Traumatol 2008:25:170-176.

10. Zerman N, Cavalleri G. Traumatic injuries to permanent incisors. Endod Dent Traumatol 1993;9:61-64.

11. Borssén E, Holm A-K. Traumatic dental injuries in a cohort of 16-years-olds in northern Sweden. Dental Traumatol 1997;13:276280.

12. Andreasen JO, Ravn JJ. Epidemiology of traumatic dental injuries to primary and permanent teeth in a Danish population sample. Int J Oral Surg 1972;1:235-239.

13. Gulinelli JL, Saito CTMH, Garcia-Júnior IR, Panzarini SR, Poi WR, Sonada CK, et al.. Occurence of tooth injuries in patients treated in hospital environment in the region of Araçatuba, Brazil during a 6-year period. Dent Traumatol 2008;24:640-644.

14. Garcia-Godoy F, Mórban-Laucer F, Corominas LR, Franjul RA, Noyola M. Traumatic dental injuries in schoolchildren from Santo Domingo. Community Dent Oral Epidemiol 1985;13:177-179.

15. Oulis CJ, Berdouses ED. Dental injuries of permanent teeth treated in private practice in Athens. Endod Dent Traumatol 1996;12:6065.

16. Marcenes W, Alessi ON, Trabert J. Causes and prevalence of traumatic injuries to the permanent incisors of school children aged 12 years in Jaraguá do Sul, Brazil. Int Dent J 2000;50:87-92.

17. Rocha MJC, Cardoso M. Traumatized permanent teeth in children assisted at the Federal University of Santa Catarina, Brazil. Dent Traumatol 2001; 17:245-249.

18. Çalişkan MK, Türkün M. Clinical investigation of traumatic injuries of permanent incisors in Izmir, Türkie. Endod Dent Traumatol 1995;11:210-213.

19. Uji T, Teramoto T. Occurrence of traumatic injuries in oromaxillary region of children in a Japanese prefecture. Endod Dent Traumatol 1988;4:63-64.

20. Luz JGC, Di Mase F. Incidence of dentoalveolar injuries in hospital emergency room patients. Endod Dent Traumatol 1994;10:188190.

Accepted March 17, 2010 